\title{
The soft-tissue attachment scars in Late Jurassic ammonites from Central Russia
}

\author{
Aleksandr A. Mironenko \\ Acta Palaeontologica Polonica 60 (4), 2015: 981-1000 doi:http://dx.doi.org/10.4202/app.00041.2013
}

Soft-tissue attachment scars of two genera and four species of Late Jurassic craspeditid ammonites from the Russian

Platform are described. A previously suggested relationship between lateral attachment scars and ammonoid hyponome is confirmed, however, a new interpretation is proposed for dorsal attachment scars: they could have been areas not only for attachment of the dorsal (nuchal) retractors, but also of the cephalic retractors. The new type of the soft-tissue attachment - anterior lateral sinuses, located between the lateral attachment scars and the aperture of the ammonite body chamber is described. Enclosed elliptical or subtriangular areas in apertural parts of the anterior lateral sinuses were found for the first time. Their presence and location suggest that this structure could have been used for attaching the funnel-locking apparatus, similar to those of coleoids. A transformation of shape and position of lateral attachment scars through the evolution of the Late Jurassic craspeditid lineage starting from platycones (Kachpurites fulgens) to keeled oxycones (Garniericeras catenulatum) is recognized.

Key words: Ammonoidea, Craspeditidae, Kachpurites, Garniericeras, attachment scars, paleobiology, Jurassic, Russia.

Aleksandr A. Mironenko [paleometro@gmail.com], Kirovogradskaya st., 28-1-101, 117519 Russia, Moscow.

This is an open-access article distributed under the terms of the Creative Commons Attribution License (for details please see creativecommons.org), which permits unrestricted use, distribution, and reproduction in any medium, provided the original author and source are credited. 
FoF Full text $(1,682.6 \mathrm{kB})$ 